\title{
GAMBARAN STATUS GIZI SISWA SEKOLAH MENENGAH PERTAMA (SMP) DI KUTA, BALI
}

\author{
I Gusti Ngurah Juniartha ${ }^{1}$, Ni Putu Emy Darma Yanti² \\ ${ }^{1,2}$ Dosen Program Studi Sarjana Keperawatan dan Profesi Ners, Fakultas Kedokteran, Universitas Udayana \\ Alamat korespondensi: emydarmayanti@unud.ac.id
}

\begin{abstract}
Abstrak
Remaja merupakan kelompok usia yang rentan mengalami masalah gizi kurang ataupun lebih. Remaja umumnya melakukan aktivitas fisik yang lebih tinggi dibandingkan usia lainnya, sehingga memerlukan pemenuhan nutrisi yang lebih banyak. Akan tetapi, kejadian gizi berlebihan pada remaja juga dapat terjadi akibat kebiasaan makan yang kurang baik sehingga jumlah masukan energi lebih banyak dibandingkan energi yang dikeluarkan. Tujuan penelitian ini adalah untuk mengetahui gambaran status gizi siswa-siswi. Jenis penelitian ini adalah kuantitatif dengan desain deskriptif analitik pada 185 siswa-siswi Sekolah Menengah Pertama (SMP) di Kuta, Bali melalui purposive sampling. Data status gizi didapatkan dengan melakukan pengukuran tinggi badan menggunakan mikrotoise dan berat badan responden menggunakan timbangan badan mekanik. Status gizi diklasifikasikan berdasarkan nilai tabel z-score IMT/ umur untuk anak usia 5-18 tahun dari pedoman Kemenkes RI tahun 2011. Hasil analisis data mendapatkan kategori status gizi siswa-siswi SMP yang terlibat sebagai responden mayoritas berada pada kategori status gizi normal yaitu 89 orang (48.10\%). Akan tetapi masih terdapat 6 siswa-siswi (3.24\%) yang mengalami obesitas. Perlu dilakukan upaya-upaya untuk mempertahankan status gizi siswa-siswi secara konsisten dan bersinergi dari berbagai pihak (orang tua, sekolah, dan pemerintah).
\end{abstract}

Kata kunci: Berat Badan, Indeks Masa Tubuh, Remaja, Status Gizi, Tinggi Badan

\begin{abstract}
Adolescents are an aggregate that is prone to experiencing malnutrition or overweight problems. Generally, they do physical activity higher than other aggregates, so they require more nutritional fulfillment. However, the excessive nutrition intake can also occur due to poor eating habits so that the amount of energy input is greater than the expended energy. The aim of this study was to describe the nutritional status of adolescent students. This is a quantitative research with analytic descriptive design using purposive sampling technique on 185 junior high school students in Kuta, Bali. Nutritional status data is obtained by measuring the height of the body using microtoise tool and body weight of the respondents using a mechanical weighing scale. Nutritional status is classified based on the BMI/age z-score table value for children aged 5-18 years from the 2011 Ministry of Health of Indonesia guidelines. The results of data analysis show that the nutritional status category of junior high school students involved as respondents is the majority in the category of normal nutritional status, namely 89 people $(48.10 \%)$. However, there are still 6 students (3.24\%) who have obese status. An efforts were need to be made to maintain the nutritional status of students consistently and in synergy from various parties (parents, schools, and the government).
\end{abstract}

Keywords: Adolescence, Body Mass Index, Body weight, Height, Nutritional status

\section{PENDAHULUAN}

Remaja merupakan kelompok usia yang rentan mengalami masalah gizi kurang ataupun lebih. Data Global School Health Survey (2015) melaporkan adanya pola makan remaja yang tidak baik yang dapat memengaruhi status gizi remaja diantaranya: tidak selalu sarapan $(65,2 \%)$, sebagian besar remaja kurang

Volume 8, Nomor 2, Agustus 2020 mengonsumsi serat sayur dan buah $(93,6 \%)$, dan sering mengkonsumsi makanan berpenyedap $(75,7 \%)$. Selain itu, remaja juga cenderung kurang melakukan aktifitas fisik (42,5\%). Hal-hal tersebut dapat meningkatkan risiko remaja menjadi gemuk, overweight, bahkan obesitas (Kemenkes RI, 2018). Remaja yang tidak mengonsumsi makanan bergizi seimbang juga berisiko mengalami penyakit Kurang 
Energi Kronis atau disebut KEK yang dapat menyebabkan berbagai penyakit infeksi dan gangguan hormonal lainnya (Kemenkes RI, 2018).

Status gizi remaja akan menentukan proses pertumbuhan dan perkembangan seorang remaja. Sesuai dengan temuan Asakura \& Satoshi (2017) yang menyebutkan bahwa nutrisi yang baik akan menunjang tumbuh kembang seorang anak maupun remaja. Disebutkan pula bahwa dengan nutrisi yang diberikan secara teratur, akan meningkatkan konsentrasi anak dalam proses belajarnya sehingga secara tidak langsung menunjang perkembangan kognitif dan nilai akademiknya di sekolah. Remaja yang teratur asupan gizi dan porsi makannya juga akan mengalami pertumbuhan yang lebih baik dibandingkan remaja yang asupan gizi dan porsi makannya tidak teratur.

Anak usia remaja memiliki kebutuhan gizi yang krusial untuk menunjang pertumbuhan sekundernya. Lijuan, dkk (2016) menyebutkan bahwa remaja putri yang cukup asupan zat besi akan dominan tetap dalam kondisi haemoglobin yang stabil ketika menstruasi dibandingkan dengan remaja putri yang kurang zat besi akan cenderung mengalami anemia pada menstruasinya. Hal serupa juga akan terjadi pada remaja pria yang akan mengalami kelelahan yang cepat sehingga akan mempengaruhi aktivitas mereka yang seharusnya tinggi. Dampak jangka panjang apabila hal ini tidak tertangani adalah anemia zat besi pada calon ibu yang akan melahirkan, dan kelelahan kronis pada pria.

Setelah mengetahui beberapa dampak akibat dari kurangnya gizi, dan mengingat remaja merupakan penerus bangsa kedepannya, menjadikan status gizi topik yang penting untuk dijadikan fokus oleh orang tua, pihak sekolah, dan pemerintah. Sesuai dengan hasil studi pendahuluan yang dilakukan sebelumnya, diketahui bahwa ketiga sekolah yang dijadikan lokasi penelitian belum pernah diadakan penelitian serupa. Hal ini menjadi potensi dan dasar untuk diadakannya penelitian untuk mengetahui status gizi anak remaja khususnya pada siswa SMP yang berusia 11-15 tahun.

\section{METODE PENELITIAN}

Penelitian ini merupakan jenis penelitian kuantitatif dengan desain deskriptif analitik. Peserta penelitian adalah 185 siswa-siswi SMP di Kuta, Bali yang ditentukan berdasarkan teknik purposive sampling. Kriteria inklusi penelitian ini adalah siswa-siswi: 1) Kelas 7 dan 8,2) tidak dalam masa cuti atau sakit saat penelitian dilaksanakan, dan 3) bersedia berpartisipasi dalam penelitian ini dengan menandatangani lembar persetujuan responden.

Variabel dalam penelitian ini adalah status gizi siswa-siswi. Status gizi diklasifikasikan sesuai dengan Z-score IMT/ umur karena responden termasuk dalam kategori anak umur 5-18 tahun (Kemenkes RI, 2011). Status gizi dikatakan sangat kurus jika nilai Zscore $<-3 \mathrm{SD}$, kurus jika nilai Z-score -3 SD hingga $2 \mathrm{SD}$, normal jika Z-score $>2$ $\mathrm{SD}$, gemuk jika nilai $Z$-score $>1 \mathrm{SD}$ hingga $2 \mathrm{SD}$, dan obesitas jika nilai Z-score $>2 \mathrm{SD}$ (Kemenkes RI, 2011). Hasil IMT dapat diketahui dengan melakukan pengukuran berat badan dan tinggi badan. Pengukuran berat badan menggunakan timbangan badan mekanik dan pengukuran tinggi badan menggunakan mikrotoise yang dilakukan dalam satu kali waktu pengukuran.

Hasil penelitian ini dianalisis secara univariat untuk mengetahui gambaran status gizi siswa-siswi SMP di Kuta, Bali. Data kemudian disajikan dalam bentuk distribusi frekuensi karena menggunakan skala kategorik.

\section{HASIL PENELITIAN}

Distribusi frekuensi karakteristik responden digambarkan pada tabel 1 dan 
distribusi status gizi responden disajikan

pada tabel 2.

Tabel 1.

Distribusi Karakteristik Responden $(\mathrm{n}=185)$

\begin{tabular}{|c|c|c|}
\hline Karakteristik & $\mathbf{f}$ & $\%$ \\
\hline \multicolumn{3}{|l|}{ Jenis Kelamin } \\
\hline Laki-Laki & 93 & 50.27 \\
\hline Perempuan & 92 & 49.73 \\
\hline \multicolumn{3}{|l|}{ Usia } \\
\hline 11 tahun & 1 & 0.54 \\
\hline 12 tahun & 65 & 35.14 \\
\hline 13 tahun & 94 & 50.81 \\
\hline 14 tahun & 24 & 12.97 \\
\hline 15 tahun & 1 & 0.54 \\
\hline
\end{tabular}

Tabel 2.

Distribusi Status Gizi Responden $(\mathrm{n}=185)$

\begin{tabular}{ccc}
\hline Kategori Status Gizi (IMT/U) & $\mathbf{f}$ & $\mathbf{\%}$ \\
\hline Sangat Kurus (<-3SD) & 0 & 0 \\
\hline Kurus (-3SD s/d <-2SD) & 68 & 36.75 \\
\hline Normal (-2SD s/d 1SD) & 89 & 48.10 \\
\hline Gemuk (>1SD s/d 2SD) & 22 & 11.89 \\
\hline Obesitas (> 2SD) & 6 & 3.24 \\
\hline
\end{tabular}

Tabel 1 menunjukkan jumlah responden berjenis kelamin laki-laki lebih banyak satu orang dibandingkan responden perempuan yaitu 93 orang. Sedangkan berdasarkan usia responden mayoritas berusia 13 tahun yaitu 94 orang $(50.81 \%)$. Tabel 2 menunjukkan kategori status gizi siswa-siswi SMP yang terlibat sebagai responden mayoritas berada pada kategori status gizi normal yaitu 89 orang (48.10\%). Akan tetapi masih terdapat 6 siswa-siswi (3.24\%) yang mengalami obesitas.

\section{PEMBAHASAN}

Hasil penelitian menunjukkan mayoritas responden berada pada kategori status gizi normal. Hasil penelitian ini mendukung penelitian Dya dan Adiningsih (2019) yang juga menemukan mayoritas siswa Sekolah Menengah Atas yang dilibatkan sebagai peserta penelitian dengan status gizi normal. Nuryani dan Rahmawati (2018) menyebutkan dari 134 siswa yang dilibatkan sebagai responden,
$67.9 \%$ memiliki status gizi normal. Status gizi normal menggambarkan kecukupan nutrisi pada seseorang atau keseimbangan antara jumlah energi yang masuk ke dalam tubuh dan energi yang dikeluarkan tubuh.

Secara umum, konsumsi makanan berkaitan erat dengan status gizi. Bila makanan yang dikonsumsi mempunyai nilai gizi yang baik, maka status gizi juga baik, sebaliknya bila makanan yang dikonsumsi kurang nilai gizinya, maka akan menyebabkan kekurangan gizi. Sholeha (2014) mendapatkan ada hubungan perilaku makan dengan IMT pada remaja. Kebiasaan jajan merupakan perilaku makan yang berpengaruh terhadap kualitas diet dan IMT. Konsumsi jajanan dengan porsi besar dan frekuensi sering dapat meningkatkan risiko obesitas, sebaliknya mengonsumsi jajanan sebelum merasa lapar akan meningkatkan kualitas diet pada anak -anak (Nuru \& Mamang, 2015). Patcheep (2011) juga menjelaskan beberapa faktor yang memengaruhi perilaku makan dan pemilihan makan pada remaja salah satunya adalah teman sebaya. 
Hal tersebut menggambarkan pentingnya kontrol faktor lingkungan sekitar remaja dalam pemenuhan status nutrisi seimbang untuk mencegah terjadinya malnutrisi maupun obesitas pada remaja.

Pemenuhan kebutuhan asupan gizi berbeda antar individu. Hal ini tergantung dari usia, jenis kelamin, aktivitas, berat badan, dan tinggi badan (Thamaria, 2017). Hasil penelitian ini menemukan mayoritas siswa SMP yang terlibat sebagai responden berusia 13 tahun dan berjenis kelamin laki-laki. Usia 13 tahun merupakan usia sekolah dengan karakteristik nafsu makan yang cenderung meningkat secara alamiah (Muhilal, 2006). Sari (2011) menyebutkan bahwa anak usia sekolah perlu mendapatkan perhatian yang lebih terhadap pola makan sehari-hari dari orang tua dan lingkungan sekitarnya karena akan membentuk pola makan anak selanjutnya.

Hasil penelitian ini juga mendapatkan masih adanya siswa-siswi yang mengalami obesitas. Sejalan dengan penelitian Dya dan Adiningsih (2019) yang juga menemukan $28.6 \%$ remaja yang yang terlibat dalam penelitiannya mengalami obesitas. Penelitian Noer, Kustanti, \& Fitiriyanti (2018) menemukan obesitas dimulai saat seseorang menginjak pubertas dikarenakan pola kebiasaan makan yang tidak teratur, lemahnya kontrol orang tua, diikuti peningkatan kegiatan sekolah yang menyebabkan peningkatan nafsu makan serta pengaruh teman sebaya.

Fraser et al (2012) menyatakan seseorang yang mengkonsumsi makanan cepat saji pada usia 13 tahun meningkatkan risiko 1,23 kali menjadi obesitas pada usia 15 tahun atau dapat meningkatkan IMT $0,08 \mathrm{~kg} / \mathrm{m}^{2}$. Remaja yang memiliki asupan zat gizi makro berlebihan, frekuensi konsumsi makanan cepat saji yang sering, kurangnya aktivitas fisik, memiliki ibu dan ayah dengan status obesitas, dan tidak sarapan, berisiko lebih terhadap terjadinya obesitas (Kurdanti dkk., 2015). Wulandari, Muniroh, dan
Susila (2015) menemukan anak yang kelebihan berat badan memiliki asupan energi yang lebih besar dibandingkan anak dengan status gizi normal.

Remaja yang mengalami ketidakseimbangan nutrisi dapat menimbulkan berbagai macam penyakit. Dya dan Adiningsih (2019) menemukan bahwa status gizi merupakan salah satu penyebab terjadinya gangguan siklus menstruasi pada remaja wanita. Penelitian Weiss et al. (2004) menyebutkan dari 112 remaja dengan masalah obesitas di Amerika Serikat, 23 remaja (21\%) mengalami intoleransi glukosa. Tidak hanya masalah secara fisiologis, tetapi status gizi yang berlebih ataupun kurang pada remaja dapat menimbulkan gangguan psikologis seperti gambaran tubuh negatif (Sahputri, 2015). Selain itu, remaja yang mengalami obesitas juga merasakan adanya bullying atau ejekan dari temannya sehingga mengganggu psikologisnya (Noer, Kustanti, \& Fitiriyanti, 2018).

Berbagai permasalahan baik secara fisik maupun psikis yang dapat dialami oleh remaja sebagai akibat dari pemenuhan nutrisi yang tidak adekuat memerlukan penatalaksanaan secara komprehensif. Nurcahyani, Suaib, dan Istejo (2020) menemukan terdapat pengaruh edukasi gizi terhadap asupan energi dan protein pada remaja putri SMP di Makasar. Pemberian edukasi melalui penyuluhan menggunakan media leaflet berhasil meningkatkan pengetahuan mengenai gizi serta mampu meningkatkan asupan energi dan protein siswa SMP (Pakhri, Sukmawati, \& Nurhasanah, 2018). Hasil penelitian Asrar, Hadi, dan Boediman (2009) mendapatkan adanya hubungan pola asuh orang tua dan pola makan dengan status gizi pada anak. Pola asuh yang dimaksud adalah perilaku yang dipraktikkan oleh orang tua ataupun pengasuh lainnya dalam pemberian makanan hingga dukungan emosional yang dibutuhkan anak selama tahap tumbuh-kembang. 


\section{SIMPULAN DAN SARAN}

Kategori status gizi siswa-siswi SMP yang terlibat sebagai responden mayoritas berada pada kategori status gizi normal. Akan tetapi, masih terdapat siswasiswi yang mengalami obesitas. Untuk itu, perlu dilakukan berbagai upaya untuk mempertahankan status gizi siswa-siswi yang sudah baik dan meningkatkan status gizi siswa-siswi yang masih kurang secara konsisten dan bersinergi dengan berbagai pihak (orang tua, sekolah, dan pemerintah). Salah satu upaya yang dapat dilakukan adalah melalui pendidikan kesehatan secara berkala sehingga siswasiswi dapat menerapkan pola makan yang baik dengan nutrisi seimbang.

\section{UCAPAN TERIMAKASIH}

Penulis mengucapkan terimakasih kepada Unit Penelitian dan Pengabdian Masyarakat (UPPM) Fakultas Kedokteran Universitas Udayana yang telah memberikan dukungan finansial terhadap penelitian ini.

\section{DAFTAR PUSTAKA}

Asakura, K. \& Satoshi, S. (2017). School lunches in Japan: their contribution to healthier nutrient intake among elementary-school and junior highschool children. Public Health Nutrition; Cambridge. 20(9): 15231533. DOI: 10.1017/S1368980017000374

Asrar, M., Hadi, H., \& Boediman, D. (2009). Pola asuh, pola makan, asupan zat gizi dan hubungannya dengan status gizi anak balita masyarakat Suku Nualu di Kecmatan Amahai Kabupaten Maluku Tengah Provinsi Maluku. Jurnal Gizi Klinik Indonesia, $\quad$ 6(2): $\quad$ 84-94. https://jurnal.ugm.ac.id/jgki/article/vi ew/17716/11497

Dya, N. M. \& Adiningsih, S. (2019). Hubungan antara status gizi dengan siklus menstruasi pada siswi MAN 1
Lamongan. Amerta Nutr, 310-314. DOI: 10.2473/amnt.v3i4.2019. 310314

Fraser, L.K., Clarke, G.P., Cade, J.E., \& Edwards, K.L. (2012). Fast food and obesity: A spatial analysis in a large United Kingdom population of children aged 13-15. Am J Prev Med, 42(5):e77-85.

Kementerian Kesehatan RI. (2011). Keputusan Menteri Kesehatan Republik Indonesia. (Direktorat Bina Gizi).

Kementerian Kesehatan RI. (2018). Kenali Masalah Gizi yang Ancam Remaja Indonesia. Diunduh dari https://www.kemkes.go.id/article/vie w/18051600005/kenali-masalahgizi-yang-ancam-remajaindonesia.html

Kurdanti, W., Suryani, I., Syamsiatun, N. H., Siwi, L. P., Adityanti, M. M., Mustikaningsih, D., \& Sholihah, K. I. (2015). Faktor-faktor yang mempengaruhi kejadian obesitas pada remaja. Jurnal Gizi Klinik Indonesia, 11(4): 179-190. https://jurnal.ugm.ac.id/jgki/article/vi ew/22900/15594

Lijuan, W., Jing, S., Jian, H., Hong, L., Jin, L. (2016). Iron status of first-year junior high school students in rural boarding school among nine provinces in China. Journal of hygiene research, 45(6) 911-937.

Muhilal, D. D. (2006). Gizi seimbang untuk anak usia sekolah dasar. Jakarta: PT. Primamedia Pustaka.

Noer, E. R., Kustanti, E. R., \& Fitriyanti, A. R. (2018). Perilaku gizi dan faktor psikososial remaha obes. Jurnal Gizi Indonesia (The Indonesian Journal of Nutrition), 6(2): 109-113. https://ejournal.undip.ac.id/index.ph p/jgi/article/view/19130/13588

Nurcahyani, I., Suaib, F., \& Istejo, I. (2020). Pengaruh Edukasi Gizi terhadap Peningkatan Asupan Energi dan Protein pada Remaja Putri SMP Al-Ishlah Maros. Ghidza: Jurnal Gizi 
Dan Kesehatan, 4(1), 100-106. https://doi.org/10.22487/ghidza.v4i1. 35

Nuru, H. \& Mamang, F. (2015). Association between snacking and obesity in children: a review. International Journal of Community Medicine and Public Health, 2(3): 196-200.

DOI: http://dx.doi.org/10.18203/23946040.ijcmph20150472

Nuryani \& Rahmawati (2018). Kebiasaan jajan berhubungan dengan status gizi siswa anak sekolah di Kabupaten Gorontalo. Jurnal Gizi Indonesia (The Indonesian Journal of Nutrition), $\quad$ 6(2): $\quad$ 114-122. https://ejournal.undip.ac.id/index.ph p/jgi/article/view/16774/13590

Pakhri.A, Sukmawati, \& Nurhasanah. (2018). Pengaruh Edukasi Gizi Terhadap Pengetahuan Gizi Dan Asupan Energi, Protein, Dan Besi Remaja. Media Kesehatan Politeknik Kesehatan Makassar, 13(1), 39-43. https://doi.org/10.32382/medkes.v13 i1.97

Patcheep, K. (2011). Factors Influencing Thai Adolescents' Eating Behaviour. Thesis, School of Nursing Science, Faculty of Medicine and Health Science, University od East Anglia.

Sahputri, D. L. (2015). Hubungan antara ststus gizi dan gambaran tubuh remaja putri di SMA Negeri 3 Cimahi. Skripsi tidak dipublikasikan. Program Studi Ilmu Keperawatan, Fakultas Kedokteran dan Ilmu Kesehatan Universitas Islam Negeri Syarif Hidayatullah. http://www.repository.uinjkt.ac.id/ds pace/bitstream/123456789/28934/1/ Diza\%20Liane\%20Sahputrifkik.pdf.
Sari, F. (2011). Faktor-faktor yang berhubungan dengan terjadinya obesitas pada anak di TK YPI Ibnu Syam, Cempaka Putih dan Waladun Shaleh Kecamatan Banuhampu Kabupaten Agam Tahun 2011. Fakultas Keperawatan, Universitas Andalas, Padang. http://repo.unand.ac.id/id/eprint/165

Sholeha, L. (2014). Hubungan perilaku makan terhadap indeks massa tubuh pada remaja di SMP YMJ Ciputat. Skripsi tidak dipublikasikan. Program Studi Ilmu Keperawatan, Fakultas Kedokteran dan Ilmu Kesehatan Universitas Islam Negeri Syarif Hidayatullah. http://repository.uinjkt.ac.id/dspace/b itstream/123456789/25583/1/LIA\%2 0SHOLEHA-FKIK.pdf

Thamaria, N. (2017). Bahan ajar: Penilaian status gizi. Pusat Pendidikan Sumber Daya Manusia Kesehatan: Badan Pengembangan dan Pemberdayaan Sumber Daya Manusia Kesehatan, Kementerian Kesehatan RI.

Weiss, R., Dziura, J., Burgert, T. S., Tamborlane, W. V, Taksali, S. E., Yeckel, C. W., ... Caprio, S. (2004). Obesity and the Metabolic Syndrome in Children and Adolescents. New England Journal of Medicine, 350(23), 2362-2374. https://doi.org/10.1056/NEJMoa031 $\underline{049}$

Wulandari, NWM, Muniroh, L., Susila, T. Asupan energi dan aktivitas fisik berhubungan dengan z-score IMT/U anak sekolah dasar di daerah perdesaan. Media Gizi Indonesia, 10(1):51-56 